\title{
PREVALENCE OF BULLYING AND PERCEIVED SOCIAL SUPPORT AMONG STUDENTS IN PESHAWAR
}

\author{
Waleed Ahmad ${ }^{1}$, Muhammad Saqib Siddique ${ }^{2}$, Ruqqia Jahangir ${ }^{3}$, Rabia Rahim ${ }^{4}$
}

\section{ABSTRACT:}

\section{OBJECTIVES:}

This study aimed to investigate the prevalence of bullying and perceived social support among students in Peshawar, Pakistan.

\section{METHODOLOGY:}

It was a cross-sectional descriptive survey, conducted in different private and government sector schools, colleges and universities of Peshawar (November2019February 2020). A total of 1000 students participated in the study. We employed a stratified sampling technique and selected a proportion of students from every academic year. Female students aged 15-24 were included in the study. Informed consent was taken from the students and the concerned authorities of the institutes. A questionnaire was designed to assess the prevalence of bullying behavior and the availability of perceived social support. Pre-testing of the questionnaire was performed on $10 \%$ of the population. The obtained data were analyzed in SPSS version 21.

\section{RESULTS:}

The prevalence of bullying was more in university students as compared to college and school students. Similarly, most of the private sector students were the victims of bullying. Family and friends were highly perceived as social support.

\section{CONCLUSION:}

A multidisciplinary approach involving affected children, their parents, school personnel, media, non-governmental organizations, and security units are required to achieve an effective approach for the prevention of violence targeting children in schools as victims and/or perpetrators.

KEYWORDS: Violence, Bullying, Harassment, Depression, Anxiety Peshawar. J Gandhara Med Dent Sci. 2020; 7(1): 39-45 


\section{Correspondence}

${ }^{1}$ Waleed Ahmed, Consultant Psychiatrist, Department of Psychiatry, Mercy Teaching Hospital. Peshawar

Cell\# +92-345-9148231.

Email. Dr.waleed@outlook.com

${ }^{2}$ Consultant Psychiatrist, Pak International

Medical College, Peshawar

${ }^{3}$ House Officer, Department of Surgery,

Mercy Teaching Hospital. Peshawar

${ }^{4}$ House Officer, Department of Surgery,

Mercy Teaching Hospital. Peshawar

\section{INTRODUCTION:}

In 2012 the Canadian province Ontario ${ }^{1}$ proposed a law which states that "bullying means repeated and aggressive behavior by a pupil where the behavior is intended by the pupil to cause, or the pupil ought to know that the behavior would be likely to cause, harm, fear or distress to another individual, including psychological harm or harm to the individual"s reputation, and the behavior occurs in a context where there is a real or perceived power imbalance between the pupil and the individual based on factors such as size, strength, age, intelligence, peer group power, economic status, social status, religion, ethnic origin, sexual orientation, family circumstances, gender, race, disability or the receipt of special education". Bullying is generally a word or statement, which is used against a person who seems to be less powerful, low self-esteem or having low socioeconomic status ${ }^{2}$. Bullying is so common that approximately all the people go through it at some point in their life ${ }^{2}$. In schools mostly bullies go for the physical appearance, academic records or family backgrounds and the reason behind all this is of course aggression (verbal or physical), grudges, jealousy, insecurities, and poor problemsolving abilities ${ }^{3}$. Bullying can be of many types i.e. physical bullying includes hitting, pushing, harming or using force on the victim ${ }^{4}$. The other is verbal bullying which comprises harassing or intimidation statements e.g. taunting, teasing, name-calling which is related to psychological intimidation too that results in depression and anxiety ${ }^{5}$. A survey conducted in Australia, ${ }^{6}$ estimated that $30 \%$ of males and $40 \%$ of females experiences mental health problems, which can be observed even at the age of 50. In comparison with physical bullying, verbal bullying has more adverse and long-term effects ${ }^{7}$. The relational bullying and cyberbullying are indirect bullying ${ }^{8}$. The relational bullying is used for a social freeze out of the victim through manipulation of the social relationships by bullies to target the reputation of the victims. Physical and cyber-bulling can be on a peak in middle school children while verbal bullying can last up to high school ${ }^{9}$. All these types of bullying are interrelational, approximately $10 \%$ of bullies exhibit a consistently high rate of bullying over time; boys are more likely to be classified as bullies than girls ${ }^{9}$. Bullies mostly exhibit defiant behavior and seemly reported as attention deficit hyperactivity disorder and opposition defiant disorder ${ }^{10}$. The victims have low self-esteem, anxious, less assertive and insecure. They also face problems in social gatherings, which they usually avoid resulting in loneliness. Researchers documented that victims suffered from more severe anxiety problems in which social anxiety is mostly reported in adulthood and they are also prone to personality problems ${ }^{7}$. In 2017 the New York Times published an article on child-committed suicide after bullied which is also the tragic reality of the bullying ${ }^{11}$. Bullying can also occur in adulthood. Bullying in the 
workplace has received significant attention; this bullying can take the form of sexual harassment, attempts to extract favors, excluding people from meetings, gossip, and other forms of overt hostility ${ }^{12}$. However, particularly sexual harassment, are legally actionable and can result in lawsuits ${ }^{13}$. Bullying others is not healthy or justifiable behavior, but reasons for bullying are often rooted in emotional pain or difficult family history ${ }^{14}$. Being a victim of bullying can result in difficult emotions such as anger, shame, anxiety, and isolation ${ }^{15}$. In UK, the incidents of bullying in medical schools were up to thirty-eight per $\operatorname{cent}^{16}$, whereas in India ${ }^{17}$ it was reported cases were about fifty per cent while unreported cases were ninety per cent. Similarly, in Pakistan, ${ }^{18}$ a study conducted on medical health professionals and it found high prevalence of bullying among them. The purpose of our study was to find out the prevalence of bullying in different educational level students, educational sectors and their perceived social support.

\section{METHODOLOGY:}

It was a cross-sectional descriptive study. This study was conducted from November 2019 to February 2020. A total of 1000 Students were recruited after taking informed consent. The inclusion criteria were 16-24 years of girls from different institutes. A stratified sampling technique was used; from every year the proportional number of students were selected for the study. A questionnaire was designed for this study to assess the prevalence of bullying and their perceived social support. Pre-testing of the questionnaire was done. Chi-square test and descriptive statistics were applied to analyse the data.

\section{RESULTS:}

Table 1: Prevalence of Bullying in Students with Different Educational Levels

\begin{tabular}{|l|c|c|c|c|c|}
\hline \multirow{2}{*}{ Education } & \multicolumn{2}{|c|}{ Experiences Bullying } & Total & \multirow{2}{*}{$\begin{array}{c}\text { Chi-square } \\
\text { value }\end{array}$} & P-value \\
\cline { 2 - 4 } & Yes & No & & \\
\hline Matric & $149(71.3 \%)$ & $60(28.7 \%)$ & $209(100 \%)$ & & \\
\hline Intermediate & $152(55.3 \%)$ & $123(44.7 \%)$ & $275(100 \%)$ & & \\
University & $305(59.1 \%)$ & $211(40.9 \%)$ & $516(100 \%)$ & \multirow{2}{*}{13.75} & $<0.001$ \\
\hline
\end{tabular}

Table 2: Prevalence of Bullying in Students of Educational Sectors

\begin{tabular}{|l|c|c|c|c|c|}
\hline \multirow{2}{*}{$\begin{array}{c}\text { Educational } \\
\text { Sectors }\end{array}$} & \multicolumn{2}{|c|}{ Experiences Bullying } & Total & $\begin{array}{c}\text { Chi-square } \\
\text { value }\end{array}$ & P-value \\
\cline { 2 - 4 } & Yes & No & & \\
\hline Government & $166(31.7 \%)$ & $358(68.3 \%)$ & $524(100 \%)$ & & \\
\hline Private & $248(52.1 \%)$ & $228(47.9 \%)$ & $476(100 \%)$ & 27.48 & $<0.001$ \\
\hline
\end{tabular}




\section{Social Support}

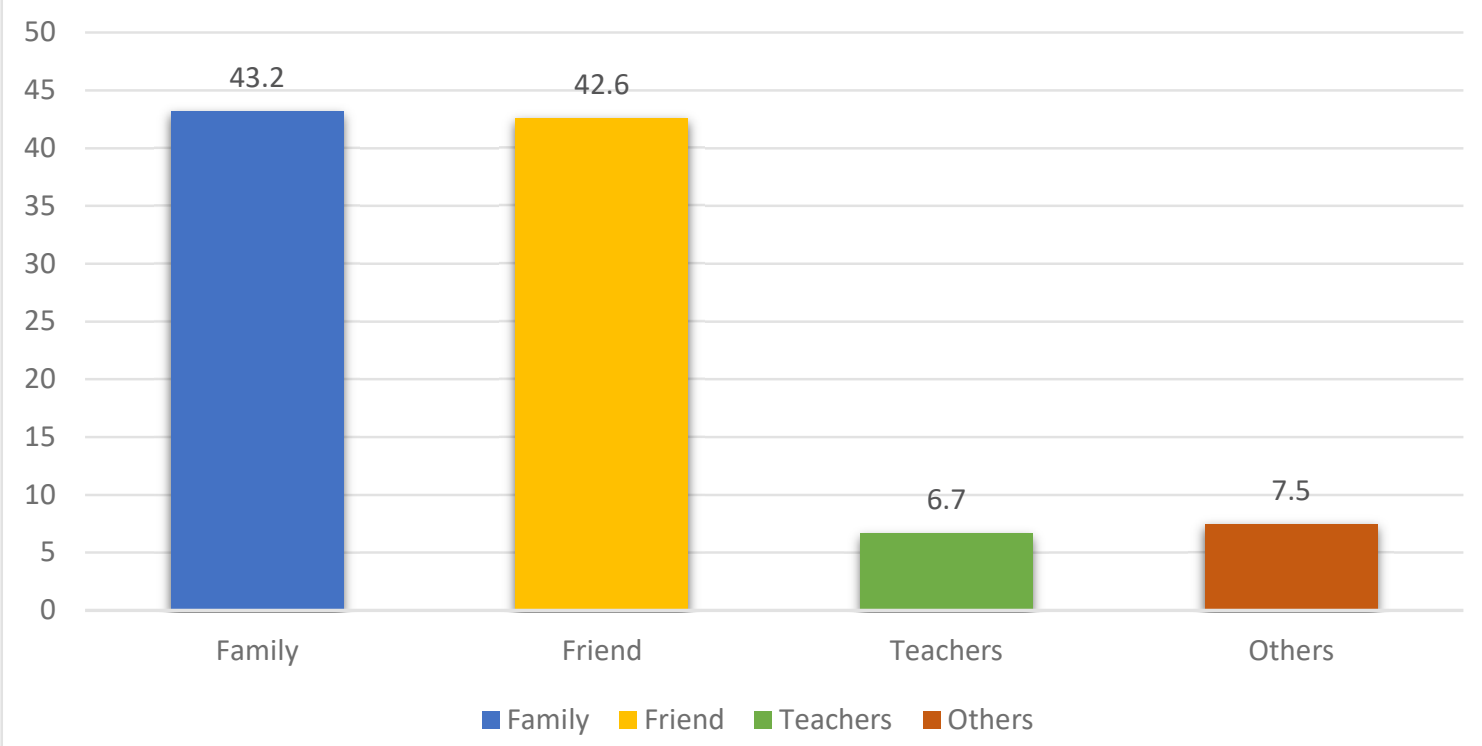

Figure 1: Level of Social Support of the Students

\section{DISCUSSION:}

Bullying is a solemn issue, that has strong linkages with gender, age, loss of appetite and sleep, low performance in education and suicidal thoughts ${ }^{19}$. A study conducted in Toronto, ${ }^{20}$ suggested that in every hour students were being bullied and bullying is specifically related to the classroom activities. Bullying is more prevalent in academic settings in the context of Pakistan ${ }^{21}$. A study conducted in Pakistan, ${ }^{22}$ reported that $63.8 \%$ of junior doctors experienced bullying whereas $66.7 \%$ of them witnessed the bullying of others. Mostly victims were Asians, black, and females. In school-going adolescents of Pakistan, $41.3 \% \quad(n=4676)$ were the victims of bullying however the prevalence of bullying in females were $35.5 \%{ }^{23}$. In our study (Table 1 ), the incidents of bullying were high among matric (71.3\%), intermediate $(55.3 \%)$ and university $(59.1 \%)$ female students $(p<0.001)$. In
Pakistan, 52\% medical students reported the bullying ${ }^{24}$. In this study, Table 2 shows the prevalence of bullying among government and private sectors educational institutes. Most of the private sector students $(59.1 \%, \mathrm{n}=248)$ experienced the bullying as compared to government sectors students $(31.7 \%$, $\mathrm{n}=166)$. A study conducted in Pakistan ${ }^{25}$ (Khyber Pakhtunkhwa), reported low incidents of bullying in private sector workplace and positive relation between workplace bullying and thoughts to quit. A research conducted in three countries (Sri Lanka, Myanmar, and Pakistan) found that the adolescents who were victims of bullying reported higher level of depressive symptoms ${ }^{25}$. Social support from family is important in endorsing upright psychological wellbeing. There was evidence that higher levels of support from friends and moderate (but not high) family support was able to protect bullied adolescents from poor academic achievement ${ }^{26}$. In 
our study (Figure 1), the students reported high level of social support from family and then friends. Perceived social support from teachers were minimum, which should be consider evaluating the reasons and enhance their contribution in the safeguard of students. A study found that low level of social support to the victims of bullying leads to poor mental health of the students ${ }^{27}$. This study will provide lay out to the authorities to take actions against bullying in the educational settings and provide social support to them. Through proper anti-bullying action plan the prevalence of bullying can be reduced and students will excel in their career with confidence.

\section{CONCLUSION:}

It was determined that the extent of bullying among students is high, as demonstrated through this study. The authorities should take action to reduce it in educational settings and provide them a healthy environment.

\section{LIMITATIONS:}

This study was more specifically for female students and excluded male students. It also didn"t address the causes or reasons for bullying among students.

\section{REFERENCES:}

1. Mitchell PJ. Ontario"s equity and inclusive education strategy reviewed. Institute of Marriage and Family Canada. 2012:1-11.

2. Deschamps R, McNutt K. Cyberbullying: what's the problem? Can Public Adm. 2016;59(1):45-71.
3. Olweus D. Bullying at school: basic facts and effects of a school-based intervention program. J Child Psychol Psychiatry. 1994;35(7):1171-90.

4. Ramsey CJ. Teachers' experiences with student bullying in five rural middle schools [dissertation on the internet]. North Carolina: Western Carolina University; 2010. Available from: https://libres.uncg.edu/ir/wcu/f/Ramsey 2010.pdf

5. Salmivalli C, Peets K. Bullies, victims, and bully-victim relationships in middle childhood and early adolescence. In: Rubin KH, Bukowski WM, Laursen B, editors. Handbook of peer interactions, relationships, and groups. New York: Guilford Press; 2009. p. 322-40.

6. Lines D. An approach with namecalling and verbal taunting. Pastoral Care Educ. 2001;19(2):3-9.

7. Wolke D, Lereya ST. Long-term effects of bullying. Arch Dis Child. 2015;100(9):879-85.

8. Brighi A, Guarini A, Melotti G, Galli S, Genta ML. Predictors of victimisation across direct bullying, indirect bullying and cyberbullying. Emotional Behav Difficulties. 2012;17(3-4):375-88.

9. Kruijshaar ME, Barendregt J, Vos T, De Graaf R, Spijker J, Andrews G. Lifetime prevalence estimates of major depression: an indirect estimation method and a quantification of recall bias. Eur J Epidemiol. 2005;20(1):10311.

10. Robson C, Witenberg RT. The influence of moral disengagement, morally based self-esteem, age, and gender on traditional bullying and 
cyberbullying. J Sch Violence.

2013;12(2):211-31.

11. Mears DP, Moon MM, Thielo AJ. Columbine revisited: myths and realities about the bullying-school shootings connection. Victims Offenders. 2017;12(6):939-55.

12. Namie G, Lutgen-Sandvik PE. Active and passive accomplices: the communal character of workplace bullying. Int J Commun. 2010;4:31.

13. Durlak JA, Weissberg RP, Dymnicki $A B$, Taylor RD, Schellinger KB. The impact of enhancing students" social and emotional learning: a metaanalysis of school-based universal interventions. Child Dev. 2011;82(1):405-32.

14. Garrett AG. Bullying in American schools: causes, preventions, interventions. North Carolina: McFarland; 2010.

15. Gunn JF, Goldstein SE. Bullying and suicidal behavior during adolescence: a developmental perspective. Adolesc Res Rev. 2017;2(2):77-97.

16. Paice E, Aitken M, Houghton A, FirthCozens J. Bullying among doctors in training: cross sectional questionnaire survey. BMJ. 2004;329:658-9.

17. Bairy KL,

Thirumalaikolundusubramanian $\mathrm{P}$, Sivagnanam G, Saraswathi S, Sachidananda A, Shalini A. Bullying among trainee doctors in Southern India: a questionnaire study. J Postgrad Med. 2007;53(2):87-90.

18. Ahmer S, Yousafzai AW, Bhutto N, Alam S, Sarangzai AK, Iqbal A. Bullying of medical students in Pakistan: a cross-sectional questionnaire survey. PLoS One. 2008;3(12):e3889.

19. Klomek AB, Sourander A, Gould M. The association of suicide and bullying in childhood to young adulthood: a review of cross-sectional and longitudinal research findings. Can J Psychiatry. 2010;55(5):282-8.

20 . Bigsby MJ. Seeing eye to eye? comparing students' and parents' perceptions of bullying behaviors. Sch Soc Work J. 2002;27(1):37-57.

21. Ahmad S, Kalim R, Kaleem A. Academics" perceptions of bullying at work: insights from Pakistan. Int J Educ Manage. 2017;31(2):204-20.

22. Imran N, Jawaid M, Haider II, Masood Z. Bullying of junior doctors in Pakistan: a cross-sectional survey. Singapore Med J. 2010;51(7):592-5.

23. Shaikh MA. Bullying victimization among school-attending adolescents in Pakistan. J Pak Med Assoc. 2013;63(9):1202-3.

24. Razzaghian M, Ghani U. Effect of workplace bullying on turnover intention of faculty members: a case of private sector universities of Khyber Pakhtunkhwa, Pakistan. Bus Econ Rev. 2014;6(1):40-51.

25. Murshid NS. Bullying victimization and mental health outcomes of adolescents in Myanmar, Pakistan, and Sri Lanka. Child Youth Serv Rev. 2017;76:163-9.

26. Rothon C, Head J, Klineberg E, Stansfeld S. Can social support protect bullied adolescents from adverse outcomes? a prospective study on the effects of bullying on the educational achievement and mental health of adolescents at secondary schools in East London. J Adolesc. 2011;34(3):579-88. 
27. Rigby KE. Effects of peer victimization in schools and perceived social support on adolescent well-being. J Adolesc. 2000;23(1):57-68.

1.

\section{CONTRIBUTORS}

1. Waleed Ahmed - Concept \& Design; Final Approval

2. Mohammad Saqib Siddique - Data Analysis/Interpretation

3. Ruqqia Jahangir - Data Acquisition; Data Analysis/Interpretation; Drafting Manuscript

4. Rabia Rahim - Concept \& Design; Critical Revision; Supervision

LICENSE: JGMDS publishes its articles under a Creative Commons Attribution Non-Commercial Share-Alike license (CC-BY-NC-SA 4.0). COPYRIGHTS: Authors retain the rights without any restrictions to freely download, print, share and disseminate the article for any lawful purpose. It includes scholarly networks such as Research Gate, Google Scholar, LinkedIn, Academia.edu, Twitter, and other academic or professional networking sites. 